\title{
ARTIKKELIT
}

\section{Ikääntyvien kuntoutujien fyysinen aktiivisuus ja paikallaanolo laitoskuntoutusjakson aikana}

\author{
Katri Turunen ${ }^{1}$, Marjo-Riitta Anttila ${ }^{1,2}$, Jenni Kumpumäki ${ }^{1}$,Timo Rantalainen ${ }^{1}$, \\ Mika Pekkonen ${ }^{2 *}$, Taija Juutinen Finni ${ }^{1}$, Sarianna Sipilä ${ }^{1}$ \\ ${ }^{1} J y v a ̈ s k y l a ̈ n ~ y l i o p i s t o$, Liikunta- ja terveystieteiden tiedekunta, Jyväskylä \\ ${ }^{2}$ Kuntoutus Peurunka, Laukaa, \\ "tutkimuksen toteutuessa, nyt Invalidiliiton kuntoutus Oy, Validia Kuntoutus
}

\begin{abstract}
Fyysinen aktiivisuus on tärkeää sairauksista, vammoista tai heikentyneestä elämänhallinnasta kuntoutuessa ja ylläpidettäessä saavutettuja kuntoutumistuloksia. Tämän pilottitutkimuksen tarkoituksena oli kuvata ikääntyvien kuntoutujien fyysistä aktiivisuutta ja paikallaanoloa kuntoutuslaitoksessa. Tutkimus toteutettiin työkykyä ylläpitävän ja parantavan valmennuksen ja sydänkuntoutuksen kursseilla. Tutkimukseen osallistui 19 keskimäärin 57-vuotiasta miestä ja naista, joiden fyysistä aktiivisuutta ja paikallaanoloa mitattiin liikemittarilla viiden kuntoutuspäivän aikana. Tulokset osoittivat, että kuntoutujat olivat liikkumatta suurimman osan hereillä oloajasta. Toisaalta kuntoutujille kertyi lähes viikoittaisen terveysliikuntasuositusten mukainen määrä liikuntaa keskimäärin päivittäin. Verrattuna vastaavan ikäisiin suomalaisiin keskimäärin kurssilaiset olivat fyysisesti aktiivisempia jakson aikana.

Tutkimuksen tuottamaa tietoa voidaan hyödyntää suunnitellessa hyvän kuntoutuskäytännön mukaisia, yhtäjaksoista paikallaan oloa vähentäviä intensiivijaksoja kuntoutuslaitoksissa. Jatkossa on tärkeää mitata fyysistä aktiivisuutta ja paikallaanoloa intensiivijaksojen välisinä aikoina kuntoutujien arjessa sekä selvittää fyysisen aktiivisuuden merkitystä kuntoutumistavoitteiden saavuttamisessa ja ylläpitämisessä. Lisäksi on tärkeää selvittää kuntoutuksen vaikutuksia fyysiseen aktiivisuuteen ja paikallaanoloon satunnaistetuissa kontrolloiduissa koeasetelmissa.
\end{abstract}

\section{Johdanto}

Fyysinen aktiivisuus on lihasten tahdonalaisesti tuottamaa liikettä, joka lisää energiankulutusta (Caspersen ym. 1985). Fyysinen aktiivisuus pitää sisällään kaiken päivän aikana kertyvän liikkumisen suunnitellusta liikunnasta arkisten askareiden lomassa kertyvään liikuskeluun. Sään- nöllinen fyysinen aktiivisuus on hyödyllistä terveydelle ja hyvinvoinnille. Vähäinen fyysinen aktiivisuus puolestaan lisää useiden sairauksien (Lee ym. 2012; Brown ym. 2012) ja toiminnanvajauksien (Fielding ym. 2017; Stenholm ym. 2016) sekä kuoleman (Lee ym. 2018) riskiä. Vähäisen fyysisen aktiivisuuden lisäksi paikallaanolo eli pitkäkestoinen istuminen, loikoi- 
leminen tai makaaminen valveilla ollessa (Tremblay ym. 2017), vaikuttaa negatiivisesti rasva- ja sokeriaineenvaihduntaan, sydän- ja verenkierto- sekä tuki- ja liikuntaelimistön toimintaan. Pitkään jatkuvalla paikallaanololla on välittömiä vaikutuksia esimerkiksi lihaskudoksessa, jonka insuliiniresistenssi kasvaa sekä rasvahappojen kuljetus ja hapetus heikentyvät (Rynders ym. 2018; Bergouignan ym. 2011; Bergouignan ym. 2013). Fyysisen aktiivisuuden ja paikallaanolon vaikutukset ovat toisistaan riippumattomia. Terveydelle haitallista on tauoton, pitkäkestoinen istuminen, ja kaikkein suurimmassa riskissä ovat henkilöt, jotka istuvat työssään ja/tai vapaa-aikanaan runsaasti ja liikkuvat vähän (Chau ym. 2013).

Tutkimustulosten mukaan suomalaiset aikuiset istuvat suuren osan valveillaoloajastaan. Lisäksi fyysinen aktiivisuus on intensiteetiltään pääsääntöisesti kevyttä, 1,6-2,9 MET:n (metabolic equivalent on lepoaineenvaihdunnan kerrannainen) intensiteetillä tapahtuvaa liikkumista. Suomalaiset istuvat, makaavat tai seisovat lähes 11 tuntia päivässä, mikä vastaa 76 prosenttia päivittäisestä valveillaoloajasta (liikemittarin mittausajasta). Vain vajaa neljännes suomalaisista liikkuu kestävyysliikuntasuosituksen verran eli reippaasti vähintään 150 minuuttia tai rasittavasti 75 minuuttia viikossa (Husu ym. 2016). Keskimäärin länsimaissa aikuisten liikkumattomuus ja fyysinen aktiivisuus ovat samalla tasolla kuin Suomessa (Loyen ym. 2017; Spittaels ym. 2012; Hansen ym. 2012). Henkilöt, joilla on pitkäaikaissairauksia kuten diabetes (Morrato ym. 2007), sydän- ja verisuonisairaus (Vasankari ym. 2018), keuhkosairaus (Saunders ym. 2016), nivelrikko (Daugaard ym. 2018) tai masennus (Hamer \& Stamatakis 2014), liikkuvat vielä vähemmän kuin väestö keskimäärin. Fyysisen aktiivisuuden on todettu vähenevän iän myötä, tosin yksilöiden välinen vaihtelu liikkumisessa on iäkkäämmillä suurempaa kuin nuoremmissa ikäluokissa (Hansen ym. 2012; Husu 2016).

Käypä Hoito -suosituksen mukaan fyysinen aktiivisuus kuuluu pitkäaikaissairauksien, ku- ten valtimotautien, diabeteksen, rappeuttavien tuki- ja liikuntaelinsairauksien, ahtauttavien keuhkosairauksien, muistisairauksien, depression ja useiden syöpäsairauksien, ehkäisyyn, hoitoon ja kuntoutukseen (Liikunta: Käypä hoito 2016). Myös Sosiaali- ja terveysministeriön linjauksessa liikkuminen on nostettu keskeiseksi osaksi sairauksien ennaltaehkäisyä, hoitoa ja kuntoutusta (STM Muutosta liikkeellä 2013). Kuntoutus on suunnitelmallista ja monialaista toimintaa, jonka tavoitteena on yksilön toimintakyvyn, itsenäisen pärjäämisen, elämänhallinnan ja hyvinvoinnin sekä työelämässä olevilla työkykyisyyden edistäminen (Järvikoski \& Härkäpää 2008). Fyysinen aktiivisuus on näiden tavoitteiden saavuttamisessa ensiarvoisen tärkeää. Lisäksi fyysinen aktiivisuus auttaa ylläpitämään saavutettuja kuntoutustuloksia (Saran ym. 2018).

Suomen kuntoutusjärjestelmässä Kansaneläkelaitos (Kela) järjestää työelämässä oleville ammatillista kuntoutusta sekä lääkinnällistä kuntoutusta henkilöille, joilla on sairauteen tai vammaan liittyvä suoritus- ja osallistumisrajoite. Kelan järjestämää ja korvaavaa laitoskuntoutusta toteuttavat valitut yksityiset palveluntuottajat. Se on ollut pääsääntöisesti pitkäkestoista ja ryhmämuotoista laitoskuntoutusta, jossa noudatetaan kuntoutukselle määriteltyjä laatuvaatimuksia koskien kuntoutuksen sisältöä, toteuttamista ja henkilöstöä (Kela avo- ja laitosmuotoisen kuntoutuksen standardi 2016).

Laitosmuotoiseen kuntoutukseen sisältyy moniammatillisen kuntoutusohjelman lisäksi kuntoutuksen tavoitteiden toteutumista tukeva muu ohjattu yhteisöllinen toiminta sekä ruokailu ja majoitus kuntoutuslaitoksessa (Hiekkala, Hämäläinen \& Pekkonen 2016, 335). Tyypillistä kurssimuotoista kuntoutusta ovat olleet esimerkiksi ammatilliseen kuntoutukseen kuulunut TYK-kuntoutus (nykyisin KIILA-kuntoutus) sekä harkinnanvaraiset kuntoutus- ja sopeutumisvalmennuskurssit eri sairausryhmille (esim. sydäntaudit).

Kuntoutuskurssit muodostuvat yleensä kahdesta tai useammasta jaksosta, joiden kuntou- 
tuskurssipäivät sisältävät tavallisesti noin viisi tuntia fyysistä aktiivisuutta sisältäviä toimintoja, jota täydentävät omatoiminen liikunta sekä kuntoutuksen tavoitteita tukevaan muuhun toimintaan ja ohjelmaan osallistuminen. Laitoskuntoutusjaksoilla kuntoutujilla on käytössään liikkumiseen soveltuvat ja aktivoivat tilat, monipuoliset laitteet ja terveydenhuollon ammattilaisten tuki. Kuntoutuja on aktiivinen toimija ja hänelle mahdollistetaan osallistuminen oman kuntoutuksen tavoitteiden asettamiseen ja kuntoutussuunnitelman laatimiseen. Tavoitteiden, joihin useimmiten liittyy fyysinen aktiivisuus, toteutumista tuetaan henkilökohtaisilla asiantuntijakäynneillä (esimerkiksi lääkäri, sairaanhoitaja, fysioterapeutti, erityistyöntekijät) ja ryhmäohjelmalla. Ryhmäohjelma sisältää esimerkiksi ohjattua liikuntaa ulkona ja sisällä (liikunta- ja kuntosalilla sekä altaalla) sekä monipuolisia ryhmäkeskusteluja psykososiaalisista ja fyysisistä teemoista (Hiekkala, Hämäläinen \& Pekkonen 2016, 337; Kela avoja laitosmuotoisen kuntoutuksen standardi 2016).

Toistaiseksi tiedetään varsin vähän kuntoutujien päivittäisestä aktiivisuudesta kuntoutusprosessin aikana. Tämä tutkimus toteutettiin pilottina suuremmalle ikääntyvien, kuntoutumassa olevien henkilöiden fyysistä aktiivisuutta selvittäneelle tutkimukselle, joten tarkoituksena oli testata liikemittarin käyttöä ja sen keräämän aineiston analysointia. Tässä artikkelissa kuvataan kuntoutumassa olevien, keskimäärin 57-vuotiaiden, henkilöiden liikemittarilla mitattua fyysistä aktiivisuutta ja paikallaanoloa viisipäiväisen laitosmuotoisen kuntoutusjakson aikana.

\section{Aineisto ja menetelmät}

\section{Osallistujat}

Tämä pilottitutkimuksen aineisto kerättiin syys-marraskuussa 2014 Jyväskylän yliopiston ja Kuntoutus Peurungan yhteisessä tutkimushankkeessa. Kyseessä on kuvaileva poikkileikkaustutkimus, jonka vapaaehtoiset tutkittavat osallistuivat Kelan kurssimuotoiseen kuntoutukseen Peurungan kuntoutuskeskuksessa Laukaassa, Keski-Suomessa. Kuntoutujat $(\mathrm{N}=20)$ osallistuivat joko sydänsairautta sairastavien aikuisten kuntoutuskurssille (sydän, n=9) tai työkykyä ylläpitävään ja parantavaan valmennukseen (TYK, $\mathrm{n}=11$ ).

Sydänkuntoutusjaksolla kohderyhmänä olivat sydänsairautta sairastavat aikuiset, joilla sairaudesta johtuvat lääketieteelliset ja toiminnalliset rajoitukset vaikeuttivat päivittäistä elämää. TYK-kuntoutusryhmä oli suunnattu ikääntyville kuntoutujille, joilla on työkykyä alentava sairaus ja riski työkyvyttömyyteen seuraavien viiden vuoden aikana. TYK-kuntoutuksen tavoitteena oli parantaa kuntoutujan työkykyä, jotta hän voi jatkaa omassa työssään tai siirtyä terveydentilalleen sopivampiin työtehtäviin. Kurssipäivien ohjelma vaihtelee kurssin mukaan sisältäen ohjattua liikuntaa, henkilökohtaisia asiantuntijakäyntejä sekä ryhmäohjelmaa (esimerkki Taulukossa 1).

Taulukko 1. Esimerkki kuntoutuskurssien ohjatun ohjelman sisällöstä yhden päivän ajalta.

\begin{tabular}{lcc}
\hline & \multicolumn{2}{c}{ Kuntoutuskurssi } \\
\hline Kurssipäivän ohjelma & TYK & Sydän \\
klo 8.15-9.15 & Toiminnallinen harjoitus & Kuntosaliharjoitus \\
\hline klo 9.30-10.15 & Kuntosaliharjoitus & Kävelylenkki \\
\hline $10.30-11.15$ & Lounas & Lounas \\
\hline $11.30-12.45$ & Ryhmäkeskustelu & Lehtien lueskelua tai ulkoilua \\
\hline $13.00-14.00$ & Ryhmäkeskustelu & Ryhmäkeskustelu \\
\hline $14.15-15.45$ & Ryhmäkeskustelu & Pilates sisäliikunta \\
\hline $16.00-16.45$ & Keilausharjoitus & Luento \\
\hline
\end{tabular}


Kuntoutus Peurungan tutkimus- ja kehittämiskoordinaattori valitsi tutkimusajankohtana toteutuvat kurssit, joilla tutkimus oli mahdollista toteuttaa. Yliopiston tutkija tiedotti kaikkia kurssille osallistuneita kuntoutujia tutkimuksesta kolmella TYK- ja kahdella sydänkurssilla. Vapaaehtoisesti tutkimukseen lähteneet kuntoutujat allekirjoittivat tutkimukseen osallistumisesta tietoon perustuvan suostumuksen, jota ennen heidät oli perehdytetty tutkimuksen tarkoitukseen, toteutukseen sekä tutkimuksesta osallistujille mahdollisesti aiheutuviin hyötyihin ja haittoihin. Tutkimus toteutettiin niin, ettei se häirinnyt kuntoutusta. Kuntoutujille kerrottiin selkeästi, ettei tutkimus liity heidän kuntoutukseensa eikä tutkimuksesta kieltäytyminen vaikuta kuntoutukseen millään tavoin. Tutkimuksessa hyödynnettiin ainoastaan suostumuksen perusteella kerättyä kysely- ja liikemittariaineistoa sekä kuntoutujille yhteistä strukturoitua päiväohjelmaa.

Jyväskylän yliopiston eettinen toimikunta antoi puoltavan lausunnon tutkimukselle 25.8.2014. Kela myönsi tutkimukselle luvan 18.9.2014.

\section{Aineiston keruu}

Fyysistä aktiivisuutta mitattiin liikemittarilla (Hookie AM20 Traxmeet Ldt, Espoo, Finland). Se kerää tietoa (keräystaajuus $100 \mathrm{~Hz}$ mittausalueen vaihdellessa $\pm 15 \mathrm{~g}$, missä yksi g tarkoittaa maan painovoiman tuottamaa putoamiskiihtyvyyttä maanpinnan läheisyydessä, $\mathrm{g}=9.81 \mathrm{~m} / \mathrm{s}^{2}$ ), kaikesta liikkumisesta kolmisuuntaisesti mitattuina todellisina kiihtyvyyksinä. Liikemittarin keräämästä raakadatasta lasketut kiihtyvyyssignaalin keskipoikkeaman arvot (MAD, Mean Amplitude Deviation) on aikaisemmin validoitu energiankulutusta vastaan Vähä-Ypyän ja muiden (2015) tutkimuksessa. Mittari kiinnitettiin polvimittaisten pyöräilyhousujen etureiden kohdalla sijaitsevaan taskuun. Housut puettiin heti suostumuksen jälkeen ensimmäisenä kuntoutuspäivänä ja otettiin pois kuntoutusjakson päättyessä. Osal- listujia neuvottiin käyttämään housuja viitenä peräkkäisenä päivänä valveilla olon ajan pois lukien peseytyessä, saunoessa ja vesiliikunnan aikana. Tutkittavia kannustettiin toimimaan normaalisti kuntoutuskurssin ohjelman ja ohjeiden mukaisesti. Tutkittaville annettiin aktiivisuuspäiväkirja, johon he kirjasivat housujen pukemis- ja riisumisajankohdat sekä vesiaktiviteetit kestoineen. Osallistujia kehotettiin kirjamaan päiväkirjaan myös poikkeamat kuntoutusohjelmasta sekä aktiviteetit, joita he tekivät strukturoidun kuntoutusohjelman ulkopuolella.

Lisäksi osallistujilta kysyttiin lomakkeella koulutus, työn rasittavuus, koettu terveys, pitkäaikaissairaudet, liikkumista ja/tai päivittäisiä toimia rajoittavat terveysongelmat, kahden kilometrin kävelyssä esiintyvät vaikeudet sekä vapaa-ajan liikunnan harrastamisen määrä ja intensiteetti. Osallistujat raportoivat lomakkeelle painon ja pituuden; painoindeksi (body mass index, BMI) laskettiin jakamalla paino pituuden neliöllä $\left(\mathrm{kg} / \mathrm{m}^{2}\right)$. Lisäksi selvitettiin mielialaa CES-D-mittarilla (The Center for Epidemiologic Studies Depression Scale, Radloff 1977), elämänhallinnan tunnetta 13 kysymystä sisältävällä SOC-mittarilla (The Sense of Coherence Questionnaire, Antonovsky 1987) sekä myönteisiä ja kielteisiä tuntemuksia PANAS-mittarin (The Positive and Negative Affect Schedule, Watson ym. 1988) lyhennetyllä versiolla (Thompson 2007). Edeltävän kuukauden aikana toteutunutta fyysistä aktiivisuutta kysyttiin Grimbyn (1986) kehittämän mittarin muokatulla versiolla (Portegjis ym. 2016).

\section{Aineiston analysointi}

Tutkimusten mukaan kiihtyvyystieto suositellaan keräämään ja analysoimaan käsittelemättömänä niin sanotussa raakamuodossa ilman ennalta määriteltyjä, tulkinnallisesti haastavia yksiköitä (esim. kiihtyvyyden muutosten määrää minuuttia kohden kuvaavat aktiivisuusluvut, englanniksi counts/min) (Vähä-Ypyä ym. 2015). Kiihtyvyysanturien keräämä aineisto siirrettiin tietokoneelle ja raakadata analysoitiin Matlab- 
ohjelmistoon kehitetyillä kiihtyvyyssignaalin keskipoikkeamaan (MAD) perustuvilla algoritmeilla. Fyysisen aktiivisuuden analysoinnissa tarkasteltiin kolmen mittaussuunnan kiihtyvyyden suuruutta (resultanttia), joka riippuu mittariin kohdistuvasta nettovoimasta ja joka on suoraan verrannollinen jalkaisin liikkumisen tehoon. Kerätyn tiedon perusteella fyysinen aktiivisuus luokiteltiin kolmeen luokkaan: kevyeen, reippaaseen ja rasittavaan. Luokittelu perustuu Jyväskylän yliopiston liikuntalaboratorion juoksumatolla tehtyyn kiihtyvävauhtiseen testiin, jossa mitattiin kiihtyvyysantureilla yli 60-vuotiailta eri kävelynopeuksien tuottamia kiihtyvyyksiä ja hapenkulutusta hengityskaasuanalysaattorilla. Testissä kerätystä aineistosta analysoitiin kutakin nopeutta vastaava MAD-menetelmän antama tulos ja hapenkulutus. Tässä tutkimuksessa käytetään kiihtyvyyden resultantille määriteltyjä raja-arvoja,joiden mukaan kevyt vastaa 1,5-3,5 MET:n, reipas 3,6-6,0 MET:n ja rasittava yli 6,0 MET:n tasolla tapahtuvaa liikkumista.

Lisäksi analysoitiin paikallaanoloaika (alle 1,5 MET). Paikallaanoloksi määriteltiin vähintään viiden minuutin mittainen yhtäjaksoinen paikallaanolo. Lisäksi tarkasteltiin tutkimuksen aikana voimassa olleen aikuisten terveyttä edistävän liikunnan suositusten mukaisesti vähintään 10 minuuttia yhtäjaksoisesti kestävien ja reippaalla intensiteetillä liikuttujen jaksojen määrää, keskimääräistä kestoa ja kokonaiskestoa päivässä. Analyysi kohdistui kunkin kuntoutuskurssin keskimmäiseen kolmeen kokonaiseen päivään, joiden aikana liikemittaria oli pidetty vähintään kymmenen tuntia päivässä. Ensimmäinen ja viimeinen mittauspäivä jätettiin pois analyyseista, koska ne eivät olleet kokonaisia päiviä ja mittarin mittaama aika jäi alle kymmeneen tuntiin. Koko tutkimusryhmän sekä erikseen miesten ja naisten sekä TYK- ja sydänkuntoutuskurssille osallistuneiden kuntoutujien fyysinen aktiivisuus ja paikallaanolo raportoitiin päivittäisten ja kolmen päivän keskiarvojen ja mediaanien avulla. Tutkimusaineisto on pieni, joten ryhmien väli- siä eroja ei testattu tilastollisin menetelmin. Tilastolliset analyysit toteutettiin IMB SPSS Statistics (versio 24, Chicago, IL) -ohjelmistolla.

\section{Tulokset}

Tutkimukseen osallistui 13 naista ja seitsemän miestä viideltä eri laitoskuntoutusjaksolta (3 TYK- ja 2 sydänkurssia). Hyväksytty liikemittariaineisto saatiin kaikilta naisilta ja kuudelta mieheltä. Taustatiedot osallistujista kuntoutuskursseittain on kuvattu Taulukossa 2. Tutkimuksen osallistujat olivat keskimäärin 57-vuotiaita. Miesten painoindeksi oli keskimäärin 28,0 ja naisten 29,8. Kuntoutujat kokivat terveytensä pääosin hyväksi. Enemmistö kuntoutujista raportoi olevansa fyysisesti kohtalaisen aktiivisia (kohtalaista fyysistä aktiviteettia n. kolme tuntia viikossa) ja useimmat raportoivat vähintään 11 liikuntakertaa kuukaudessa. (Taulukko 2).

Kurssien aikana osallistujat pitivät kiihtyvyysantureita keskimäärin 13,5 tuntia päivässä. Paikallaanoloa tutkittaville kertyi keskimäärin yli 9 tuntia päivässä, mikä vastaa $64 \%$ päivittäisestä mittausajasta. Kevyeen aktiivisuuteen käytettiin keskimäärin vajaa kaksi tuntia (110 minuuttia) ja reippaaseen hieman yli kaksi tuntia (136 minuuttia) päivästä. Rasittavaa aktiivisuutta kertyi alle prosentin (8 minuuttia) päivittäisestä mittausajasta. (Kuvio 1 ja Taulukko 3).

Kuntoutuskurssilaisille kertyi keskimäärin 26 yhtämittaista, vähintään 5 minuuttia kestävää paikallaanolojaksoa päivässä. Kun yhtäjaksoisen paikallaanolon katkaisemista tarkasteltiin vähintään 10 minuuttia kestävänä vähintään keskitehoisena tai reippaana liikuntana, havaittiin, että kuntoutujat liikkuivat keskimäärin kaksi kertaa päivässä lähes puoli tuntia kerrallaan. (Taulukko 4.)

Sukupuolesta ja kuntoutuskurssista riippumatta kuntoutujat viettivät suurimman osan päivittäisestä mittausajasta paikallaan eli istuen, maaten tai seisten. Sydänkurssilaiset ja miehet kerryttivät keskimäärin hieman enemmän rei- 


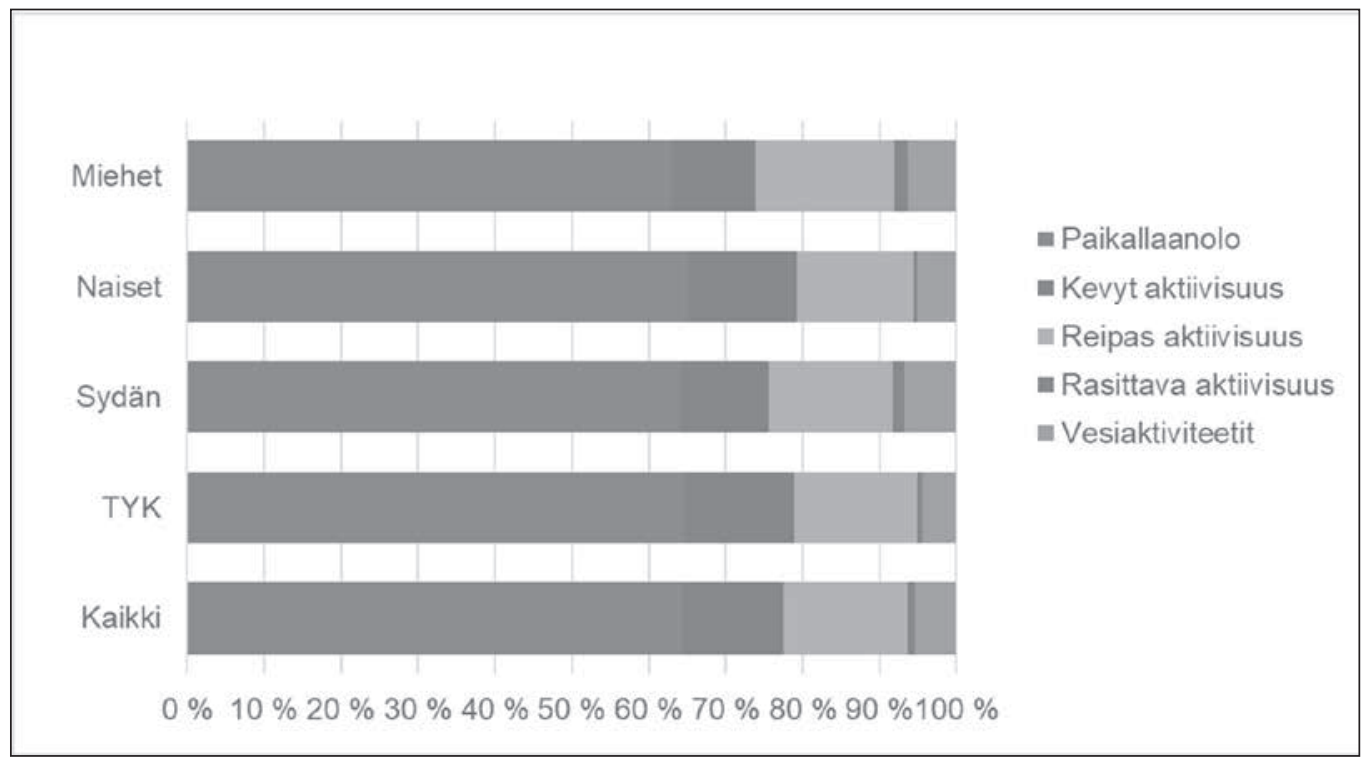

Kuvio 1. Fyysisen aktiivisunden ja paikallaanolon keskimääräiset osuudet mittausajasta (\%) kuntoutuskurssi- ja sukupuoliryhmittäin. TYK=työkykyä ylläpitävä ja parantava kuntoutus.

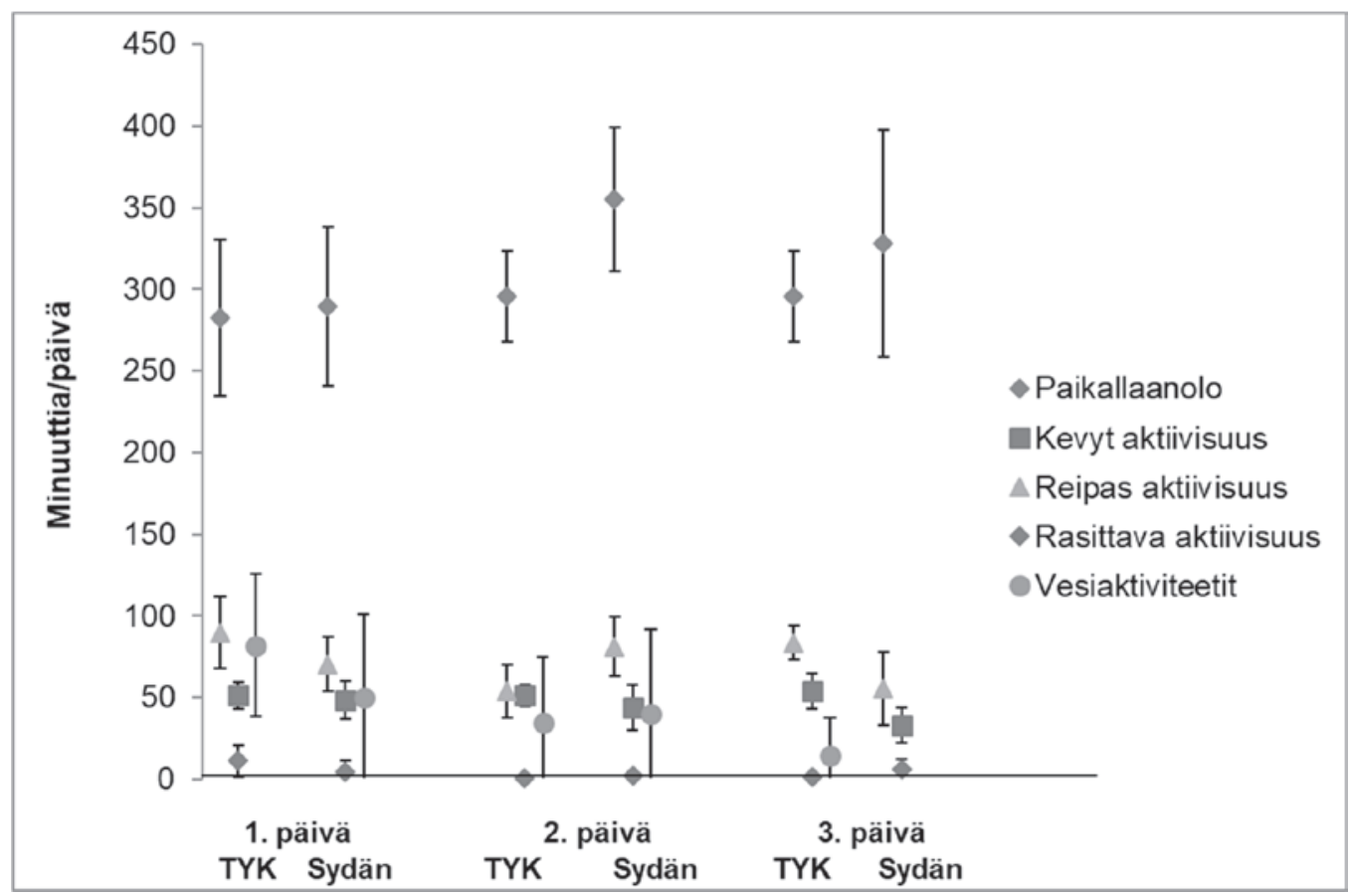

Kuvio 2. Päivittäisen kuntoutuskurssiobjelman aikainen fyysinen aktiivisuus minuutteina (keskiarvo ja 95 \% prosentin luottamusväli) kuntoutusryhmittäin. TYK= työkykyä ylläpitävä ja parantava kuntoutus 
Taulukko 2. Osallistujien taustatiedot kuntoutuskursseittain, $n=19$. TYK=työkykyä ylläpitävä ja parantava kuntoutus. ka=keskiarvo, sd=keskihajonta.

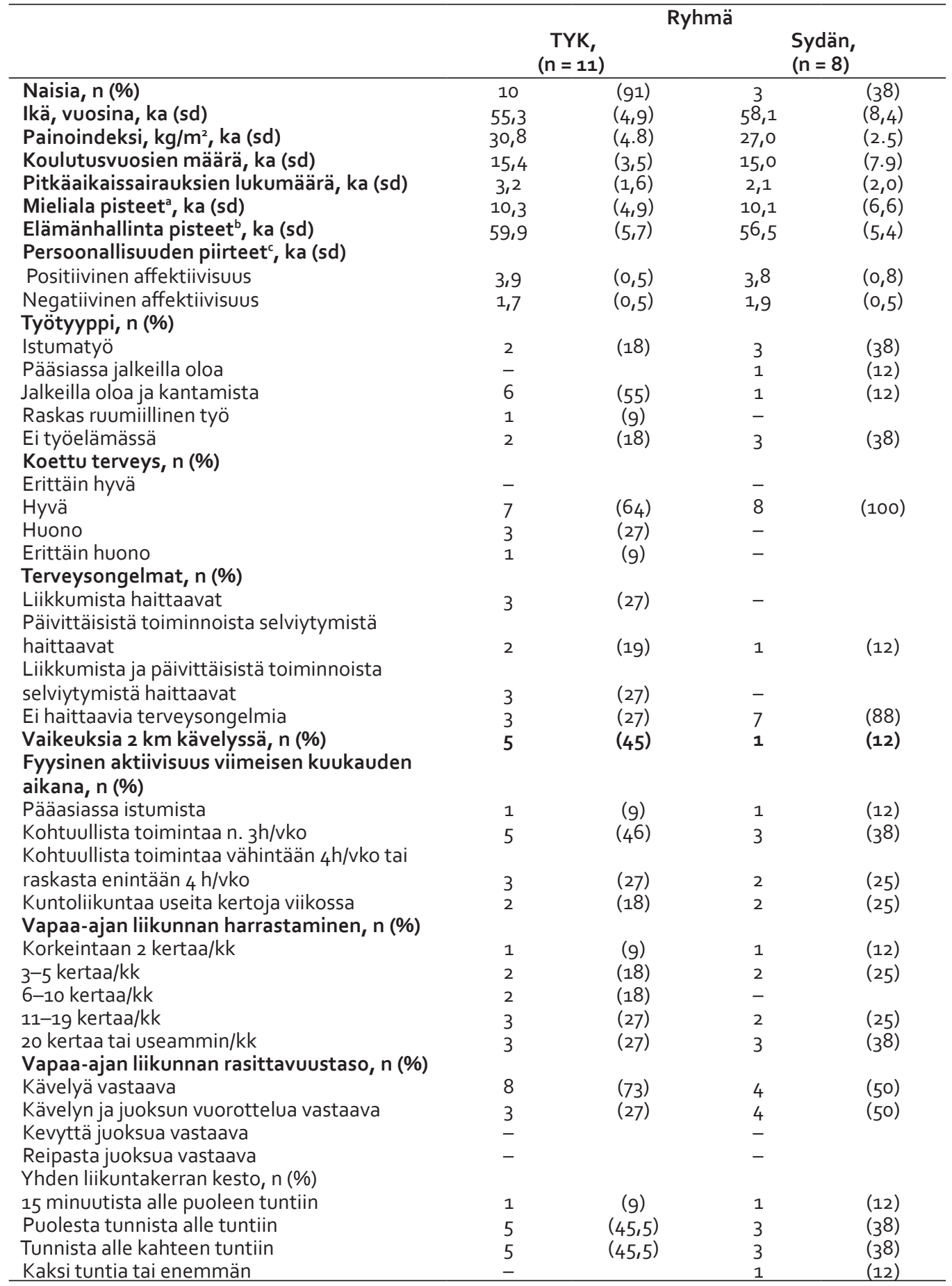

${ }^{a}$ CES-D vaihteluväli o-6o pistettä, jossa o=ei masennusoireita ja 6o=suurin mittarin antama masennusoireiden määrä;

bSOC vaihteluväli 13-91 pistettä, jossa suurempi pistemäärä kuvaa vahvempaa koherenssin tunnetta;

'PANAS vaihteluväli 1-5 pistettä, jossa suurempi pistemäärä kuvaa suurempaa positiivista tai negatiivista affektiivisuutta. 
Taulukko 3. Kurssipäivittäinen fyysinen aktiivisuus intensiteetin mukaisesti jaoteltuna, kokonaisaktiivisuus ja paikallaanolo sekä vesiaktiviteetteihin osallistuminen minuutteina, keskiarvo (ka) \pm keskihajonta (sd) Suluissa mediaani (Md). TYK=työkykyä ylläpitävä ja parantava kuntoutus.

\begin{tabular}{lccc}
\hline & Kaikki, $\mathrm{n}=19$ & $\mathrm{TYK}, \mathrm{n}=11$ & Sydän, $\mathrm{n}=8$ \\
\hline Päivä 1 & $\mathrm{ka} \pm \mathrm{sd}(\mathrm{Md})$ & $\mathrm{ka} \pm \mathrm{sd}(\mathrm{Md})$ & $\mathrm{ka} \pm \mathrm{sd}(\mathrm{Md})$ \\
\hline Paikallaanolo & $522 \pm 84(526)$ & $514 \pm 89(526)$ & $534 \pm 83(513)$ \\
Kevyt aktiivisuus & $113 \pm 22(119)$ & $122 \pm 20(122)$ & $101 \pm 17(93)$ \\
Reipas aktiivisuus & $140 \pm 36(134)$ & $147 \pm 43(138)$ & $130 \pm 25(131)$ \\
Rasittava aktiivisuus & $12 \pm 17(5)$ & $12 \pm 18(5)$ & $13 \pm 17(5)$ \\
Kokonaisaktiivisuus & $265 \pm 47(253)$ & $281 \pm 52(259)$ & $244 \pm 28(252)$ \\
Vesiaktiviteetit & $68 \pm 61(81)$ & $41 \pm 58(0)$ & $101 \pm 50(108)$ \\
\hline Päivä 2 & & & \\
\hline Paikallaanolo & $574 \pm 90(582)$ & $561 \pm 99(565)$ & $596 \pm 78(613)$ \\
Kevyt aktiivisuus & $109 \pm 28(122)$ & $112 \pm 25(114)$ & $103 \pm 32(104)$ \\
Reipas aktiivisuus & $122 \pm 41(118)$ & $114 \pm 41(109)$ & $134 \pm 42(122)$ \\
Rasittava aktiivisuus & $3 \pm 5(0)$ & $1 \pm 2(0)$ & $5 \pm 8(0)$ \\
Kokonaisaktiivisuus & $233 \pm 57(226)$ & $227 \pm 62(203)$ & $242 \pm 52(226)$ \\
Vesiaktiviteetit & $37 \pm 57(0)$ & $32 \pm 57(0)$ & $43 \pm 60(0)$ \\
\hline Päivä 3 & & & \\
\hline Paikallaanolo & $549 \pm 77(531)$ & $550 \pm 86(536)$ & $548 \pm 66(529)$ \\
Kevyt aktiivisuus & $119 \pm 32(113)$ & $122 \pm 33(133)$ & $114 \pm 32(111)$ \\
Reipas aktiivisuus & $145 \pm 47(144)$ & $140 \pm 37(131)$ & $155 \pm 64(151)$ \\
Rasittava aktiivisuus & $5 \pm 13(0)$ & $3 \pm 6(0)$ & $10 \pm 20(3)$ \\
Kokonaisaktiivisuus & $269 \pm 65(266)$ & $264 \pm 68(266)$ & $279 \pm 64(260)$ \\
Vesiaktiviteetit & $38 \pm 55(0)$ & $44 \pm 64(0)$ & $30 \pm 42(0)$ \\
\hline Keskimäärin kolmessa päivässä & & & \\
\hline Paikallaanolo & $543 \pm 68(540)$ & $541 \pm 71(540)$ & $546 \pm 68(551)$ \\
Kevyt aktiivisuus & $110 \pm 22(114)$ & $120 \pm 20(121)$ & $98 \pm 19(97)$ \\
Reipas aktiivisuus & $136 \pm 34(130)$ & $134 \pm 36(130)$ & $138 \pm 31(130)$ \\
Rasittava aktiivisuus & $8512(3)$ & $5 \pm 8(3)$ & $12 \pm 16(3)$ \\
Kokonaisaktiivisuus & $46 \pm 37(53)$ & $37 \pm 35(27)$ & $58 \pm 38(53)$ \\
Vesiaktiviteetit & & &
\end{tabular}

pasta ja rasittavaa fyysistä aktiivisuutta päivittäisestä mittausajasta kuin TYK-kurssilaiset ja naiset, ero kurssien välillä oli keskimäärin 2 prosenttia ja sukupuolten välillä 3 prosenttia. (Kuvio 1.)

Kuvio 2 esittää pelkästään kuntoutuskurssipäivien strukturoidun ohjelman aikana tapahtuneen keskimääräisen fyysisen aktiivisuuden. Kuntoutuspäivät erosivat jonkin verran toisistaan fyysisen aktiivisuuden suhteen esimerkiksi niin, että kuntotestauspäivinä kertyi enemmän reipasta tai rasittavaa aktiivisuutta kuin muina päivinä. Yksilöllistä vaihtelua päiviin sisältyi kohtalaisen paljon, sillä ohjattu kuntoutusohjelma sisälsi henkilökohtaisia asiantuntijakäyntejä ja päiväohjelmaan sisältyi joinakin päivinä taukoja, jotka osa kuntoutujista hyödynsi lenkkeillen ja osa lueskellen lehtiä tai lepäillen vuoteessa. Keskimäärin kuntoutujat olivat paikallaan 5,5 tuntia, liikkuivat kevyesti 47 minuuttia, reippaasti 72 minuuttia ja rasittavasti 4 minuuttia päiväohjelman aikana. (Kuvio 2.) 
Taulukko 4. Yhtäjaksoiset paikallaanolo- ja liikuntajaksot kuntoutuskursseittain. Paikallaanolojaksolla tarkoitetaan vähintään viiden minuutin yhtämittaista paikallaan oloa. Liikuntajaksot kuvaavat vähintään 10 minuutin kestoisia intensiteetiltään vähintään reipasta liikuntaa. Keskiarvo (ka) \pm keskihajonta (sd) Suluissa mediaani (Md). TYK=työkykyä ylläpitävä ja parantava kuntoutus.

\begin{tabular}{|c|c|c|c|}
\hline & Kaikki, n=19 & TYK, $\mathrm{n}=11$ & Sydän, $n=8$ \\
\hline Päivä 1 & $\mathrm{ka} \pm \mathrm{sd}(\mathrm{Md})$ & $\mathrm{ka} \pm \mathrm{sd}(\mathrm{Md})$ & $\mathrm{ka} \pm \mathrm{sd}(\mathrm{Md})$ \\
\hline Paikallaanolojaksojen lukumäärä & $26,4 \pm 4,7(26)$ & $26,2 \pm 5,7(25)$ & $26,6 \pm 3,2(27)$ \\
\hline $\begin{array}{l}\text { Vähintään } 10 \text { minuuttia kestävien } \\
\text { liikuntajaksojen lukumäärä }\end{array}$ & $1,8 \pm 1,1(2)$ & $1,5 \pm 0,7(1)$ & $2,2 \pm 1,4(2)$ \\
\hline $\begin{array}{l}\text { Keskimääräinen vähintään } 10 \text { minuuttisen } \\
\text { liikuntajakson kesto, min }\end{array}$ & $43,7 \pm 34,6(32)$ & $33,0 \pm 16,3(28)$ & $58,3 \pm 47,8(53)$ \\
\hline $\begin{array}{l}\text { Keskimääräinen vähintään } 10 \text { minuuttisten } \\
\text { liikuntajaksojen kokonaiskesto, min }\end{array}$ & $85,3 \pm 83,4(59)$ & $51,1 \pm 30,3(46)$ & $139,1 \pm 112,5(147)$ \\
\hline \multicolumn{4}{|l|}{ Päivä 2} \\
\hline Paikallaanolojaksojen lukumäärä & $26,9 \pm 4,6(28)$ & $26,7 \pm 4,1(27)$ & $27,1 \pm 5,6(28)$ \\
\hline $\begin{array}{l}\text { Vähintään } 10 \text { minuuttia kestävien } \\
\text { liikuntajaksojen lukumäärä }\end{array}$ & $1,4 \pm 1,5$ (1) & $1,1 \pm 1,0(1)$ & $2 \pm 2(1)$ \\
\hline $\begin{array}{l}\text { Keskimääräinen vähintään } 10 \text { minuuttisen } \\
\text { liikuntajakson kesto, min }\end{array}$ & $21,9 \pm 21,8(16)$ & $12,7 \pm 7,6(12)$ & $34,6 \pm 28,7(24)$ \\
\hline $\begin{array}{l}\text { Keskimäääranen vähintään } 10 \text { minuuttisten } \\
\text { liikuntajaksojen kokonaiskesto, min }\end{array}$ & $34,3 \pm 50,3(17)$ & $16,0 \pm 13,3(15)$ & $63,1 \pm 72,8(41)$ \\
\hline \multicolumn{4}{|l|}{ Päivä 3} \\
\hline Paikallaanolojaksojen lukumäärä & $25,2 \pm 5,1(25)$ & $26,3 \pm 5,2(26)$ & $23,3 \pm 4,6(22)$ \\
\hline $\begin{array}{l}\text { Vähintään } 10 \text { minuuttia kestävien } \\
\text { liikuntajaksojen lukumäärä }\end{array}$ & $2,5 \pm 1,3(2)$ & $2,3 \pm 0,6(2)$ & $3,0 \pm 2,1(3)$ \\
\hline $\begin{array}{l}\text { Keskimääräinen vähintään } 10 \text { minuuttisen } \\
\text { liikuntajakson kesto, min }\end{array}$ & $19,0 \pm 8,1(18)$ & $17,2 \pm 8,8(13)$ & $22,2 \pm 6,0(20)$ \\
\hline $\begin{array}{l}\text { Keskimääräinen vähintään } 10 \text { minuuttisten } \\
\text { liikuntajaksojen kokonaiskesto, min }\end{array}$ & $50,5 \pm 50,2(38)$ & $36,5 \pm 14,3(37)$ & $76,0 \pm 80,3(52)$ \\
\hline \multicolumn{4}{|l|}{ Keskimäärin kolmessa päivässä } \\
\hline Paikallaanolojaksojen lukumäärä & $26,1 \pm 2,7(25)$ & $26,4 \pm 2,8(25)$ & $25,6 \pm 4,6(26)$ \\
\hline $\begin{array}{l}\text { Vähintään } 10 \text { minuuttia kestävien } \\
\text { liikuntajaksojen lukumäärä }\end{array}$ & $1,9 \pm 1,1(2)$ & $1,6 \pm 0,4(2)$ & $2,4 \pm 1,5(2)$ \\
\hline $\begin{array}{l}\text { Keskimääräinen vähintään } 10 \text { minuuttisen } \\
\text { liikuntajakson kesto, min }\end{array}$ & $28,0 \pm 16,2(22)$ & $21,1 \pm 9,1(19)$ & $37,4 \pm 19,6(35)$ \\
\hline $\begin{array}{l}\text { Keskimääräinen vähintään } 10 \text { minuuttisten } \\
\text { liikunta-jaksojen kokonaiskesto, min }\end{array}$ & $58,6 \pm 56,0(41)$ & $34,7 \pm 14,7(29)$ & $91,5 \pm 75,0(79)$ \\
\hline
\end{tabular}

\section{Pohdinta}

Tutkimuksen tarkoituksena oli kuvata kuntoutuskurssille osallistuvien keskimäärin 57-vuotiaiden henkilöiden paikallaanoloa ja fyysistä aktiivisuutta laitosmuotoisen kuntoutusjakson aikana. Tutkimusaineisto koostui 19 TYK- tai sydänkuntoutuskurssille osallistuvasta henki- löstä, joiden fyysistä aktiivisuutta mitattiin kuntoutuskurssin aikana liikemittarilla. Tutkimus toteutettiin syksyllä 2014, jonka jälkeen Kelan järjestämissä kuntoutuskursseissa on tapahtunut muutoksia. Pieni otoskoko ja muutokset kuntoutuskäytännössä rajoittavat tutkimuksen yleistettävyyttä. 


\section{Liikkuminen toteutui suosituksen mukaisesti}

Tulosten mukaan kuntoutuskurssilaiset liikkuivat nykyisen liikkumisen suosituksen (2 tuntia 30 minuuttia reippaalla tasolla tai 1 tunti 15 minuuttia rasittavalla tasolla viikossa) ylittävän määrän kuntoutuskurssin aikana. Aikuisten liikkumisen suositus uudistui lokakuussa 2019, jolloin siitä poistui vaade aiemman suosituksen mukaisista vähintään $10 \mathrm{mi}^{-}$ nuutin kestoisista liikkumishetkistä. Nykyisen suosituksen mukaan jo muutaman minuutin pätkät liikkumista kerrallaan riittävät (UKK 2019). Tämä tutkimus toteutui aiemman liikuntasuosituksen aikana ja siksi tulosten tulkinta perustuu aiemman suosituksen mukaisiin raja-arvoihin. Terveyttä edistävää liikuntaa, joka vastaa teholtaan reipasta kävelyä ja kestää vähintään 10 minuuttia kerrallaan, kertyi keskimäärin lähes tunti päivässä. Näyttää siltä, että kuntoutuskurssilaiset olivat keskimäärin fyysisesti jonkin verran aktiivisempia kuin suomalainen aikuisväestö Husun ja kumppaneiden (2016) tutkimuksessa. Tämä voi selittyä liikuntaa sisältävällä ohjelmalla ja liikkumiseen suotuisalla ympäristöllä sekä olosuhteiden muutoksella verrattuna tavanomaiseen elämään. Kuntoutusjakson aikana kuntoutujan on helppo keskittyä itseensä, itsehoitoon ja omiin kuntoutustarpeisiinsa arjen velvollisuuksien $\mathrm{ja} /$ tai murheiden häiritsemättä. Jokaiseen kurssipäivään oli sisälletty ohjattua ryhmämuotoista liikuntaa. Fyysisen aktiivisuuden määrä oli suurempi päivinä, jolloin kuntoutujien fyysistä kuntoa testattiin esimerkiksi kävelytesteillä.

Toisaalta tulokset osoittavat, että kuntoutujat viettivät suuren osan päivästään, keskimäärin yhdeksän tuntia, paikallaan ollen. Tämä vastaa Husun ja kumppaneiden tutkimuksessa (2016) 50-70-vuotiailla suomalaisilla havaittua päivittäistä istumis- ja makaamisaikaa. Kyseisessä tutkimuksessa istumisesta ja makaamisesta tosin oli erotettu paikoillaan seisominen, jolloin keskimääräinen paikallaanoloaika nousi 11 tuntiin valveillaoloajasta (mittausajas- ta) (Husu ym. 2016). On myös huomioitava, että Husun ja muiden (2016) tutkimuksessa liikemittaria pidettiin lantiolla, kun taas tässä tutkimuksessa sitä pidettiin reidessä, mikä heikentää tutkimustulosten vertailua toisiinsa. Liikemittaria suositellaan pitämään lantiolla, jolloin sen katsotaan mittaavan paremmin koko kehon ja kehon massakeskipisteen liikettä verrattuna raajoihin kiinnitettyyn liikemittariin (Sievänen \& Kujala 2017). Reiteen sijoitettu liikemittari on käyttökelpoinen erityisesti analysoitaessa kehon asentoa (Matthews ym. 2012). Tämän pilottitutkimuksen alkuperäisenä tarkoituksena oli kehittää kehon asennon analysointia liikemittariaineistosta ja rekisteröidä iäkkäille ja kuntoutumassa oleville henkilöille tyypillisiä alhaisen kiihtyvyyden aktiivisuutta, joten anturin kiinnityspaikaksi valikoitui reisi. Liikemittarin dataa analysoidessa kuitenkin todettiin, ettei paikoillaan seisomista voitu erotella luotettavasti istumisesta ja makaamisesta liikemittarin virransäästötila-asetusten takia. Jatkossa seisominen tulisi erotella istumisesta ja makaamisesta; seisominen on vahva stimulus keholle, sillä alaraajojen isot lihakset ovat seisoessa aktiivisia toisin kuin istuessa, joka on lähes lepoa vastaava passiivinen olotila (Pesola ym. 2015).

On mahdollista, että suunniteltu/ohjattu, reipastempoinen liikunta kuntoutuskurssipäivän aikana ja kuntoutuslaitosympäristö vaikuttavat siihen, että myös täydellinen paikallaan oleminen on suurta. Tällöin puhutaan niin sanotusta kompensaatiosta, jossa kevyt fyysinen aktiivisuus korvautuu liikkumattomuudella henkilön lisätessä reipasta tai rasittavaa liikuntaa päiväohjelmaansa (Wanigatunga ym. 2017). Kuntoutuskurssilaisilla oli useita pitkäkestoisia paikallaanolojaksoja päivittäin. Kurssiohjelmat sisälsivät paljon yhtäjaksoista istumista sisältäviä keskusteluryhmiä. Paikallaanolon suuri määrä on huolestuttavaa, sillä yhtäjaksoinen ja pitkään jatkuva paikallaanolo, kuten istuminen, on itsenäinen terveysriski riippumatta siitä, liikkuuko henkilö liikuntasuositusten mukaisesti vai ei (Chau ym. 2013; Pesola ym. 2016). 
On merkittävää, että vähäinen fyysinen aktiivisuus ja runsas paikallaanolo aiheuttavat yhteiskunnalle vähintään kolmen miljardin euron kustannukset vuosittain. Kustannuksia kerryttävät sairastelun aiheuttamat terveysmenot, työpanoksen ja verotulojen menetys sekä välillisesti myös työttömyyden, syrjäytymisen ja ikääntyvien hoivan kustannukset. (Vasankari \& Kolu 2018). Siksi yhteiskunnan jokaisen toimijan, myös kuntoutussektorin, tulisi panostaa paikallaanolon vähentämiseen. Liikkumattomuuden vähentämisessä keskeistä on tieto siitä, että lyhyetkin paikallaanolon katkaisevat liikkumispätkät ovat merkityksellisiä terveyden kannalta. Kuntoutuksessa voitaisiin yhtäjaksoista istumista ryhmäkeskustelujen aikana katkaista esimerkiksi erilaisilla toiminnallisilla tehtävillä.

Fyysinen aktiivisuus ja paikallaanolo näyttivät vaihtelevan vain vähän sukupuolen mukaan, kun taas kuntoutuskurssien välillä voi havaita eroa etenkin pidempikestoisten liikuntasuoritusten osalta. Pieni otoskoko rajoitti mahdollisten erojen tilastollista analysoimista ja tuloksien tulkinnassa on käytettävä harkintaa, sillä yksilön vaikutus tuloksiin on suurentunut. Tämä tutkimus antoi viitteitä siitä, että TYKkuntoutujat olisivat keskimäärin lihavampia ja raportoisivat enemmän terveysongelmia, jotka on aiemmissa tutkimuksissa yhdistetty vähäisempään fyysiseen aktiivisuuteen (Loyen ym. 2017; Waller ym. 2018). Mahdollisten erojen ja yhteyksien selvittämiseksi tarvitaan suuremman otoskoon tutkimuksia, joissa fyysistä aktiivisuutta mitataan paitsi laitoskuntoutuksen aikana, mutta erityisesti sen ulkopuolella, kuntoutujien omassa arjessa ja ympäristöissä.

\section{Liikkumista tulisi monitoroida}

liikemittarilla myös kuntoutusjakson ulkopuolella

Pienen otoskoon lisäksi tämän tutkimuksen heikkouksia ovat fyysisen aktiivisuuden mittaamiseen liittyvät puutteet. Tutkimuksessa käytetty liikemittari ei ollut vesitiivis, joten kuntoutuskeskusympäristössä oleellinen vesilii- kunta jäi niillä rekisteröimättä. Vesiliikuntaan käytetty aika perustuu kuntoutujien omaan raportointiin päiväkirjoissa ja siihen sisältyy epätarkkuuksia (esimerkiksi kuinka pitkä aika on vietetty saunassa tai suihkussa, onko uima-altailla uitu tai vesijumpattu vai oltu vesihierontapisteillä tai porealtaissa). Liikemittarit eivät myöskään pysty luotettavasti tunnistamaan esimerkiksi yläraajojen liikkeillä tuotettua aktiivisuutta kuten kuntosaliharjoittelua, johon kuntoutuskeskus myös tarjoaa oivalliset puitteet.

Tässä tutkimuksessa fyysistä aktiivisuutta ja paikallaanoloa seurattiin vähintään 10 tuntia päivässä viiden kurssipäivän aikana, mutta mittauksen aloitus- ja lopetuspäivä jätettiin analyysista pois vajaan mittausajan takia. Monet tutkimukset ovat havainneet, että luotettava fyysisen aktiivisuuden ja liikkumattomuuden mittaaminen edellyttää viiden peräkkäisen päivän (Sasaki ym. 2018) tai jopa viikon (Jaeschke ym. 2018) mittaista mittausta liikemittarilla. Luotettavan mittaustuloksen saamiseksi on ratkaisevaa, että mittausjakso edustaa tutkittavien tavanomaista fyysistä aktiivisuutta ja paikallaanoloa. Liikemittarin pitäminen saattaa johtaa käyttäytymisen muuttamiseen erityisesti fyysisen aktiivisuuden osalta, mutta esimerkiksi istumisen määrä pysyy pääosin ennallaan. On kuitenkin mahdollista, että mittari riisutaan pois silloin kun ei olla fyysisesti aktiivisia (Sievänen \& Kujala 2017).

Tässä tutkimuksessa mittaria ohjattiin pitämään päivittäin valveillaoloajan, mutta on mahdollista, että jotkut tutkittavista ovat riisuneet sen paljon ennen nukkumaan menoa tai sitä ei ole muistettu pukea välittömästi vesiaktiviteettien jälkeen. Tällöin mittausajan ulkopuolinen aktiivisuus tai paikallaanolo on jäänyt rekisteröimättä. Jatkotutkimuksissa tämä voitaisiin ratkaista keräämällä kiihtyvyysaineistoa vuorokauden ympäri viikon ajan johonkin kehon osaan teipatulla vesitiiviillä mittarilla. Jatkossa olisi tärkeää toistaa fyysisen aktiivisuuden seuranta liikemittarilla kurssijakson aikana, mutta myös ennen kurssijaksoa, jaksojen välissä ja kuntoutuksen päätyttyä kuntoutujan omassa 
koti- ja työympäristössä. Laitoskuntoutusjakso on poikkeusolosuhde kuntoutujan elämässä, ja vain sen ulkopuolella kerätty liikemittariaineisto edustaa kuntoutujien tyypillistä fyysistä aktiivisuutta ja paikallaanoloa. Mittaamalla fyysistä aktiivisuutta jo ennen kuntoutuksen alkua ja sen eri vaiheissa, voitaisiin myös vertailla fyysisen aktiivisuuden muutosprofiileja erilaisen aktiivisuustason omaavilla kuntoutujilla.

\section{Pilottitutkimuksen rajoitteet ja jatko- tutkimustarpeet}

Tutkimus toteutettiin neljä vuotta sitten, joten tutkimuksen tulokset eivät täysin ole yleistettävissä nykykäytäntöihin. Kuntoutuskurssijärjestelmässä on tapahtunut näinä vuosina muutoksia; Kela on korvannut esimerkiksi aiemman TYK-kuntoutuksen uudella KIILAkuntoutusmuodolla. Siinä kuntoutuksen rakenne on muuttunut niin, että pitkäkestoiset laitoskuntoutukset on korvattu avokuntoutusta täydentävillä lyhyillä intensiivijaksoilla (Kela 2016).

Myös tutkimustieto ja samalla yleinen tietoisuus vähäisen fyysisen aktiivisuuden ja paikallaanolon haitoista on lisääntynyt räjähdysmäisesti. Vuonna 2015 valtioneuvosto julkaisi kansalliset suosituksen istumisen vähentämiseksi (STM 2015). Tavoitteena on ollut ottaa käyttöön uusia innovaatioita kuten fyysistä aktiivisuutta tukevia työpisteitä, reaaliaikaisen aktiivisuuden seurannan mahdollistavia teknologioita ja kävelypalavereja. Toimintakulttuurit ja -ympäristöt kuntoutuslaitoksissa voivat uusien innovaatioiden myötä muuttua aikaisempaa enemmän fyysistä aktiivisuutta tukeviksi. Esimerkiksi etäkuntoutus on yleistynyt (Rintala ym.2018). Osana etäkuntoutusta kuntoutuja voi esimerkiksi seurata liikemittarilla fyysistä aktiivisuuttaan ja saada reaaliaikaista palautetta, mikä saattaa motivoida liikkumaan enemmän (Peel ym. 2016). Teknologioiden käytöstä kuntoutuksessa on saatu myönteisiä kokemuksia tietyin edellytyksin. On esimerkiksi tärkeää, että kuntoutusta järjestävä taho tunnistaa kuntoutujan yksilölliset tarpeet ja mahdolliset huolet, jotka liittyvät teknologian käyttöön sekä suunnittelee kuntoutuksen vastaamaan kuntoutujan kokemuksia ja kykyjä teknologioiden käyttäjänä (Anttila ym. 2019). Teknologia luo mahdollisuuksia, mutta samalla täytyy varmistaa, ettei istuen vietetty ruutuaika vie liikaa aikaa fyysiseltä aktiivisuudelta kuntoutujan elämässä.

Tämän tutkimuksen vahvuutena on kehon liikkeeseen perustuva fyysisen aktiivisuuden ja paikallaanolon mittaaminen liikemittarilla. Fyysisen aktiivisuuden ja paikallaanolon mittaaminen liikemittarilla rekisteröi kaiken liikkeen todellisina kiihtyvyyksinä toisin kuin subjektiiviset arviot omasta liikkumisesta. Lisäarvoa tutkimukseen tuo kahden erilaisen kuntoutuskurssimuodon; työelämään liittyvän TYK-kuntoutuskurssin ja sairausperusteisen sydänkuntoutuskurssilaisten fyysisen aktiivisuuden ja liikkumattomuuden seuraaminen.

Tämän tutkimuksen pilottiluonteen, pienuuden ja tutkimukseen sisältyneiden rajoitusten takia tuloksia voidaan hyödyntää ainoastaan suuntaa-antavina suunniteltaessa kuntoutusta ja siihen liittyvää fyysistä aktiivisuutta selvittäviä tutkimuksia. Kuntoutumisessa ja työkyvyn ylläpitämisessä on tärkeää edistää fyysistä aktiivisuutta ja vähentää paikallaanoloa. Jatkossa on selvitettävä fyysisen aktiivisuuden merkitystä (esim. annos-vastesuhde) kuntoutumistavoitteiden saavuttamisessa sekä seurattava fyysistä aktiivisuutta myös intensiivisen laitoskuntoutusjakson ulkopuolella. Lisäksi tarvitaan korkealaatuisia satunnaistettuja kontrolloituja tutkimuksia erilaisten kuntoutusmuotojen, kuten laitos- ja etäkuntoutuksen tai niiden yhdistelmien, sekä kuntoutuksessa hyödynnettävien teknologioiden vaikutuksista mitattuun fyysiseen aktiivisuuteen ja paikallaanoloon. 


\section{Yhteydenotto}

Katri Turunen, Tt T, tutkijatohtori

Gerontologian tutkimuskeskus ja

Liikuntatieteellinen tiedekunta

Jyväskylän yliopisto

katri.m.turunen@jyu.fi

\section{Kirjallisuus}

Antonovsky, A. (1987). Unravelling the mystery of health: How people manage stress and stay well. San Francisco CA: Jossey-Bass.

Anttila, M. R., Kivistö, H., Piirainen, A., Kokko, K., Malinen, A., Pekkonen, M. \& Sjögren, T. (2019). Cardiac Rehabilitees' Technology Experiences Before Remote Rehabilitation: Qualitative Study Using a Grounded Theory Approach. Journal of Medical Internet Research, 21 (2), e10985. doi:10.2196/10985.

Bergouignan, A., Antoun, E., Momken, I., Schoeller, D. A., Gauquelin-Koch, G., Simon, C. \& Blanc, S. (2013). Effect of contrasted levels of habitual physical activity on metabolic flexibility Journal of Applied Physiology, 114 (3), 371-379. doi: 10.1152/japplphysiol.00458.2012.

Bergouignan, A., Rudwill, F., Simon, C. \& Blanc, S. (2011). Physical inactivity as the culprit of metabolic inflexibility: Evidence from bed-rest studies. Journal of Applied Physiology, 111 (4), 1201-1210. doi: 10.1152/japplphysiol.00698.2011.

Brown, J. C., Winters-Stone, K., Lee, A. \& Schmitz, K. H. (2012). Cancer, physical activity, and exercise. Comprehensive Physiology, 2 (4), 2775-2809. doi: 10.1002/cphy.c120005.

Caspersen, C. J., Powell, K. E. \& Christenson, G. M. (1985). Physical activity, exercise, and physical fitness: Definitions and distinctions for health-related research. Public Health Reports, 100 (2), 126-131.

Chau, J. Y., Grunseit, A. C., Chey, T., Stamatakis, E., Brown, W. J., Matthews, C. E., Bauman, A. E. \& van der Ploeg, H. P. (2013). Daily sitting time and all-cause mortality: A meta-analysis. PLoS One, 8 (11), e80000. doi: 10.1371/journal.pone.0080000.

Daugaard, R., Tjur, M., Sliepen, M., Lipperts, M., Grimm, B. \& Mechlenburg, I. (2018). Are patients with knee osteoarthritis and patients with knee joint replacement as physically active as healthy persons? Journal of Orthopaedic Translation, 3 (14), 8-15. doi: 10.1016/j.jot.2018.03.001.

Fielding, R. A., Guralnik, J. M., King, A. C., Pahor, M., McDermott, M. M., Tudor-Locke, C., Manini, T. M., Glynn, N. W., Marsh, A. P., Axtell, R. S., Hsu, F. C. \& Rejeski, W.J. LIFE study group. (2017). Dose of physical activity, physical functioning and disability risk in mobility-limited older adults: Results from the LIFE study randomized trial. PLoS One, 12 (8), e0182155. doi:10.1371/journal.pone.0182155.

Grimby, G. (1986). Physical activity and muscle training in the elderly. Acta medica Scandinavica. Supplementum, 711, 233-237.

https://doi.org/10.1111/j.0954-6820.1986. tb08956.x.

Hamer, M. \& Stamatakis, E. (2014). Prospective study of sedentary behavior, risk of depression, and cognitive impairment. Medicine and Science in Sports and Exercise, 46 (4), 718-723. doi: 10.1249/MSS.0000000000000156.

Hansen, B. H., Kolle, E., Dyrstad, S. M., Holme, I. \& Anderssen, S. A. (2012). Accelerometer-determined physical activity in adults and older people. Medicine and Science in Sports and Exercise, 44 (2), 266-272. doi: 10.1249/MSS.0b013e31822cb354.

Hiekkala, S., Hämäläinen, P. \& Pekkonen, M. (2016). Laitoskuntoutus osana hyvää kuntoutuskäytäntöä. Teoksessa Autti-Rämö, I., Salminen, A-L., Rajavaara, M. \& Ylinen, A. (toim.), Kuntoutuminen (s. 335-347). Helsinki: Kustannus Oy Duodecim.

Husu, P., Suni, J., Vähä-Ypyä, H., Sievänen, H., Tokola, K., Valkeinen, H., Mäki-Opas, T. \& Vasankari, T. (2016). Objectively measured sedentary behavior and physical activity in a sample of Finnish adults: A cross-sectional study. BMC Public Health, 1 (16), 920.

doi: 10.1186/s12889-016-3591-y.

Jaeschke, L., Steinbrecher, A., Jeran, S., Konigorski, S. \& Pischon, T. (2018). Variability and reliability study of overall physical activity and activity intensity levels using $24 \mathrm{~h}$-accelerometry-assessed data. BMC Public Health, 18 (1), 8. doi: 10.1186/s12889-018-5415-8.

Järvikoski, A. \& Härkäpää, K. (2008). Kuntoutuskäsityksen muutos ja asiakkuuden muotoutuminen. Teoksessa Rissanen, P., Kallanranta, T., Suikkanen, A. (toim). Kuntoutus (s. 51-62). Helsinki: Kustannus Oy Duodecim. 
Kela. Kelan avo- ja laitosmuodoitsen kuntoutuksen standardi. Yleinen osa. Voimassa 1.5.2016 alkaen. Haettu 10.1.2019 osoitteesta: https://www.kela. fi/documents/10180/2448451/stnd_y_kl.pdf/ f870c94a-6f83-42be-a75a-c7e86485651c.

Lee, I. M., Shiroma, E. J., Evenson, K. R., Kamada, M., LaCroix, A. Z. \& Buring, J. E. (2018). Accelerometer-measured physical activity and sedentary behavior in relation to all-cause mortality: The women's health study. Circulation, 137 (2), 203-205. doi: 10.1161/CIRCULATIONAHA.117.031300.

Lee, I. M., Shiroma, E. J., Lobelo, F., Puska, P., Blair, S. N. \& Katzmarzyk PT; Lancet Physical Activity Series Working Group. (2012). Effect of physical inactivity on major non-communicable diseases worldwide: An analysis of burden of disease and life expectancy. Lancet, 380 (9838), 219-229. doi: 10.1016/S0140-6736(12)61031-9.

Liikunta. Käypä hoito -suositus. (2016). Suomalaisen Lääkäriseuran Duodecimin ja Käypä hoito -johtoryhmän asettama työryhmä. Helsinki: Suomalainen Lääkäriseura Duodecim. Haettu 2.1.2019 osoitteesta: www.kaypahoito.fi.

Loyen, A., Clarke-Cornwell, A. M., Anderssen, S. A., Hagströmer, M., Sardinha, L. B., Sundquist, K., Ekelund, U., Steene-Johannessen, J., Baptista, F., Hansen, B. H., Wijndaele, K., Brage, S., Lakerveld, J., Brug, J. \& van der Ploeg, H. P. (2017). Sedentary time and physical activity surveillance through accelerometer pooling in four European countries. Sports Medicine, 47 (7), 1421-1435. doi: 10.1007/s40279-016-0658-y.

Matthews, C. E., Hagströmer, M., Pober, D. M. \& Bowles, H. R. (2012). Best practices for using physical activity monitors in population-based research. Medicine and Science in Sports and Exercise, 44 (1 Supplement 1), S68-S76.

doi: 10.1249/MSS.0b013e3182399e5b.

Morrato, E. H., Hill, J. O., Wyatt,H. R., Ghushchyan, V. \& Sullivan, P. W. (2007). Physical activity in U.S. adults with diabetes and at risk for developing diabetes, 2003. Diabetes Care, 30 (2), 203-209. doi: $10.2337 / \mathrm{dc} 06-1128$.

Peel, N. M., Paul, S. K., Cameron, I. D., Crotty, M., Kurrle, S. E. \& Gray, L. C. (2016). Promoting Activity in Geriatric Rehabilitation: A Randomized Controlled Trial of Accelerometry. PLoS One, 11 (8), e0160906.

doi: 10.1371/journal.pone.0160906.
Pesola, A. J., Laukkanen, A., Tikkanen, O., Sipilä, S., Kainulainen, H. \& Finni, T. (2015). Muscle inactivity is adversely associated with biomarkers in physically active adults. Medicine and Science in Sports and Exercise, 47 (6), 1188-1196. doi: 10.1249/MSS.0000000000000527.

Pesola, A.J., Pekkonen, M. \& Finni, T. (2016). Miksi liiallinen istuminen on vaarallista? Lääketieteellinen aikakauskirja Duodecim, 132 (21), 1964-1971.

Portegijs, E., Sipilä, S., Viljanen, A., Rantakokko, M. \& Rantanen, T. (2017). Validity of a single question to assess habitual physical activity of community-dwelling older people. Scandinavian Journal of Medicine Es Science in Sports, 27 (11), 1423-1430. doi: 10.1111/sms.12782.

Radloff, L. S. (1991). The use of the center for epidemiologic studies depression scale in adolescents and young adults. Journal of Youth and Adolescence, 20 (2), 149-166. doi: 10.1007/BF01537606.

Rintala, A., Päivärinne, V., Hakala, S., Paltamaa, J., Heinonen, A., Karvanen, J. \& Sjögren, T. (2018). Effectiveness of technology-based distance physical rehabilitation interventions for improving physical functioning in stroke: A systematic review and meta-analysis of randomized controlled trials. Archives of Physical Medicine and Rebabilitation, 100 (7), 1339-1358.

doi: 10.1016/j.apmr.2018.11.007.

Rynders, C. A., Blanc, S., DeJong, N., Bessesen, D. H. \& Bergouignan, A. (2018). Sedentary behaviour is a key determinant of metabolic inflexibility. Journal of Physiology, 596 (8), 1319-1330. doi: 10.1113/JP273282.

Saran, T., Pedrycz, A., Mucha, D. \& Mucha, D. (2018). Follow-up monitoring of physical activity after rehabilitation by means of a mobile application: Effectiveness of measurements in different age groups. Advances in Clinical and Experimental Medicine, 27 (8), 1037-1044. doi: $10.17219 /$ acem/69131

Sasaki,J.E.,Junior,J.H., Meneguci,J., Tribess, S., Marocolo, Júnior M., Stabelini Neto, A. \& Virtuoso, Júnior, J. S. (2018). Number of days required for reliably estimating physical activity and sedentary behaviour from accelerometer data in older adults. Journal of Sports Sciences, 36 (14), 1572 1577. doi: 10.1080/02640414.2017.1403527.

Saunders, T., Campbell, N., Jason, T., Dechman, G., Hernandez, P., Thompson, K. \& Blanchard, C. M. (2016). Objectively measured steps/day in patients with chronic obstructive pulmonary 
disease: A systematic review and meta-analysis. Journal of Physical Activity and Health, 13 (11), 1275-1283. doi: 10.1123/jpah.2016-0087.

Sievänen, H. \& Kujala, U. M. (2017). Accelerometry-simple, but challenging. Scandinavian Journal of Medicine E' Science in Sports, 27 (6), 574578. doi: https://doi.org/10.1111/sms.12887.

Spittaels, H., Van Cauwenberghe, E., Verbestel, V., De Meester, F., Van Dyck, D., Verloigne, M., Haerens, L., Deforche, B., Cardon, G. \& De Bourdeaudhuij, I. (2012). Objectively measured sedentary time and physical activity time across the lifespan: A cross-sectional study in four age groups. International Journal of Behavioral Nutrition and Physical Activity, 9 (149). doi: 10.1186/1479-5868-9-149.

Stenholm, S., Koster, A., Valkeinen, H., Patel, K. V., Bandinelli, S., Guralnik, J. M. \& Ferrucci, L. (2016). Association of physical activity history with physical function and mortality in old age. The Journals of Gerontology Series A Biological Sciences and Medical Sciences, 71 (4), 496-501. doi: 10.1093/gerona/glv111.

STM. (2015). Istu vähemmän - voi paremmin! Kansalliset suositukset istumisen vähentämiseen. Sosiaali- ja terveysministeriön esitteitä. Haettu 11.1.2019 osoitteesta: http://julkaisut.valtioneuvosto.fi/bitstream/handle/10024/74517/STM_ esite_210x210_Kansalliset\%20suositukset $\% 20$ istumisen $\% 20 \mathrm{v} \%$ c3\%a4hent $\%$ c3\%a4miseksi_sisus_net_.jpg..pdf? sequence $=1$ \&isAllowed $=y$.

STM. (2013). Muutosta liikkeellä! valtakunnalliset ybteiset linjaukset terveyttä ja hyvinvointia edistävään liikuntaan 2020. Sosiaali- ja terveysministeriön julkaisuja 2013:10. Helsinki: Sosiaali- ja terveysministeriö.

Thompson, E. R. (2007). Development and validation of an internationally reliable short-form of the Positive and Negative Affect Schedule (PANAS). Journal of Cross-Cultural Psychology, 38 (2): 227242. https://doi.org/10.1177/0022022106297301.

Tremblay, M. S., Aubert, S., Barnes, J. D., Saunders, T.J., Carson, V., Latimer-Cheung, A. E., Chastin, S. F. M., Altenburg, T. M. \& Chinapaw, M. J. M. SBRN Terminology Consensus Project Participants. (2017). Sedentary behavior research network (SBRN) - terminology consensus project process and outcome. International Journal of Behavioral Nutrition and Physical Activity, 14 (1), 8. doi: 10.1186/s12966-017-0525-8.
UKK-instituutti. (2019). Aikuisten liikkumisen suositus. Haettu 22.11.2019. https://www.ukkinstituutti.fi/liikkumisensuositus/aikuisten-liikkumisen-suositus.

Vasankari, T. \& Kolu, P. (2018) Liikkumattomuuden lasku kasvaa - vähäisen fyysisen aktiivisuuden ja heikon fyysisen kunnon ybteiskunnalliset kustannukset. Raportti Valtioneuvoston kanslia, Valtioneuvoston selvitys- ja tutkimustoiminnan julkaisusarja 31/2018. Haettu 11.1.2019 osoitteesta:

https://tietokayttoon.fi/documents/10616/6354562/31-2018-Liik-

kumattomuuden+lasku+kasvaa.pdf/3dde $40 \mathrm{cf}-25 \mathrm{c} 0-4 \mathrm{~b} 5 \mathrm{~d}-\mathrm{bab} 4-6 \mathrm{c} 0 \mathrm{e}-$ c8325e35/31-2018-Liikkumattomuuden+lasku+kasvaa.pdf.pdf?version=1.0.

Vasankari, V., Husu, P., Vähä-Ypyä, H., Suni, J. H., Tokola, K., Borodulin, K., Wennman, H., Halonen, J., Hartikainen, J., Sievänen, H. \& Vasankari, T. (2018). Subjects with cardiovascular disease or high disease risk are more sedentary and less active than their healthy peers. BMJ Open Sport E Exercise Medicine, 4 (1), e000363.

doi: 10.1136/bmjsem-2018-000363.

Vähä-Ypyä, H., Vasankari, T., Husu, P., Mänttäri, A., Vuorimaa, T., Suni, J. \& Sievänen, H. (2015). Validation of cut-points for evaluating the intensity of physical activity with accelerometry-based mean amplitude deviation (MAD). PLoS One, 10 (8), e0134813. doi: 10.1371/journal.pone.0134813.

Waller, K., Vähä-Ypyä, H., Lindgren, N., Kaprio, J., Sievänen, H. \& Kujala, U. M. (2018). Self- reported fitness and objectively measured physical activity profile among older adults: A twin study. The Journals of Gerontology Series A Biological Sciences and Medical Sciences, 74 (12), 1965-1972. doi: 10.1093/gerona/gly263.

Wanigatunga, A. A., Tudor-Locke, C., Axtell, R. S., Glynn, N. W., King, A. C., McDermott, M. M., Fielding, R. A., Lu, X., Pahor, M. \& Manini, T. M. (2017). Effects of a long-term physical activity program on activity patterns in older adults. Medicine and Science in Sports and Exercise, 49 (11), 2167-2175. doi: 10.1249/MSS.0000000000001340.

Watson, D., Clark, L. A. \& Tellegen, A. (1988). Development and validation of brief measures of positive and negative affect: The PANAS scales. Journal of Personality and Social Psychology, 54 (6), 1063-1070. doi: 10.1037//0022-3514.54.6.1063. 